World Maritime University

The Maritime Commons: Digital Repository of the World Maritime University

\title{
The needs, challenges and prospects of maritime education and training in Georgia
}

\author{
George Gabedava \\ Batumi Navigation Teaching University \\ Guram Kakabadze \\ Batumi Navigation Teaching University
}

Follow this and additional works at: https://commons.wmu.se/imla2021

Part of the Education Commons

\section{Recommended Citation}

Gabedava, G. \& Kakabadze, G. (2021). The needs, challenges and prospects of maritime education and training in Georgia. In Pazaver, A., Manuel, M. E., Bolmsten, J., Kitada, M., Bartuseviciene, I. (Eds.), Proceedings of the International Maritime Lecturers' Association. Seas of transition: setting a course for the future (pp. 122-127). World Maritime University. http://dx.doi.org/10.21677/imla2021.12

This Paper is brought to you courtesy of Maritime Commons. Open Access items may be downloaded for noncommercial, fair use academic purposes. No items may be hosted on another server or web site without express written permission from the World Maritime University. For more information, please contact library@wmu.se. 
http://dx.doi.org/10.21677/imla2021.12

\title{
The needs, challenges and prospects of maritime education and training in Georgia
}

\author{
George Gabedava \\ Associate-Professor, Batumi Navigation Teaching University, Batumi, Georgia, e-mail: \\ g.gabedava@bntu.edu.ge \\ Guram Kakabadze \\ Coordinator of BNTU International Maritime Training Center, Batumi Navigation Teaching \\ University, Batumi, Georgia, e-mail: g.kakabadze@bntu.edu.ge
}

\begin{abstract}
Georgia is a maritime country. It has been associated with the sea since ancient times, and therefore maritime education in the country has existed for more than seven decades. Even today, highly trained maritime specialists graduated from the maritime institutions of Georgia continue to work successfully on ocean-going vessels flying under the Georgian flag and the flags of many other countries. About 80 to 90 percent of maritime accidents are attributable to human error. Hence it is important that seafarers be well educated and trained, able to understand and execute commands, manage risks, and solve problems in order to ensure safe and effective navigation at sea. In order for maritime training centres to graduate qualified and competitive officers and engineers for the world fleet, they must constantly upgrade equipment and techniques, improve curricula and teaching methods, attract experienced personnel, provide cadets with practice, and enhance cadet's language competence. The main purpose of this article is to study the maritime education market in Georgia, in particular, to identify problems and barriers in Georgia's maritime education system and their impact on seafarers' subsequent employment. It also identifies challenges facing Georgia's maritime training centers and proposes solutions.
\end{abstract}

Keywords: Maritime Education, METs of Georgia, Seafarers, Challenges, Solutions

\section{Introduction}

When we talk about the education of seafarers and its development, it is important to define the role of educated and qualified personnel in the field. Service flexibility is an important issue to be achieved by staffing with experienced and educated staff. Maritime education in Georgia dates back more than a few decades. The first maritime courses were opened in 1901 in the city of Poti. In the 1920s, evening maritime courses were opened in the port of Batumi, on the basis of which the Batumi Maritime Technical School was established in 1929. On March 5, 1944, by the decision of the State Committee of Defense of the USSR, the Batumi Maritime Academy was established on the basis of a Maritime Technical school.

Batumi Maritime Academy, in the half-century of its existence, has played a major role in the development of maritime affairs, not only for Georgia but for the entire Soviet Union. Highly qualified specialists trained by the school still successfully work on ocean-going ships flying under the flag of Georgia and the flags of many countries around the world. In 1992, by the 
decision of the government, Batumi Higher Maritime School was established, which in 1994 received the status of "Batumi State Maritime Academy", but the current status of the Maritime Academy was determined by Resolution № 84 of October 2009: Legal Entity of Public Law Teaching University - Batumi State Maritime Academy.

Currently, there are two higher maritime higher education institutions and six seafarer training centers in Georgia:

- $\quad$ Batumi Navigation Teaching University and the adjacent seafarers' training center;

- $\quad$ Batumi State Maritime Academy and the adjacent seafarers' training center;

- $\quad$ Seafarers' Training Center "ANRI";

- $\quad$ Seafarers' Training Center "Equator";

- $\quad$ Poti Maritime Training Center;

- $\quad$ Qualship Georgia

Their main purpose is to train qualified personnel in accordance with modern requirements for employment in the merchant fleet and maritime transport infrastructure. Today, about 12,000 sailors are registered in Georgia, who are employed on merchant ships of different countries.

Accordingly, in the main part of the article we will review the main challenges of maritime education in the country.

\section{Current status of MET in Georgia}

In order to determine employment prospects in the maritime field, it is important to analyze what knowledge and competence different educational institutions provide to the graduates; To what extent do the existing training system, programs, and training courses comply with the legislation of Georgia and the requirements of International Convention on Standards of Training, Certification and Watchkeeping for Seafarers (STCW).

The International Maritime Organization - IMO pays particular attention to providing adequate education and training for seafarers. Its requirements for the qualification of maritime personnel are set out in the International Convention on Standards of Training, Certification and Watchkeeping for Seafarers (STCW), adopted by the International Maritime Organization on 7 July 1978. The Convention entered into force on 28 April 1984. By this act, the IMO member states undertook to transpose the standards and regulations set out in the STCW Convention into national law to ensure that all Member States' seafarers are qualified and have the professional knowledge to perform their duties to the fullest.

This convention has a "white list". The "White List" includes a list of countries in which full compliance with the International Convention on Standards of Training, Certification and Watchkeeping for Seafarers (STCW) is presented and established. The list was developed by competent and impartial members of the International Maritime Organization in accordance with Administrative Licensing, Training Center, Certificate Re-validation, and Navigation Regulations. Georgia is also a member of this list. In addition, it should be noted that Georgian maritime higher education institutions are authorized and the educational programs are accredited by the National Center for Education Quality Enhancement and comply with the European standard. 
Table 1 shows the maritime faculties of each Georgian maritime higher education institution, and appropriate educational programs (educational programs at the undergraduate and graduate levels).

Table 1

Georgian Maritime Higher Education Institutions

\section{Batumi Navigation Teaching University}

\begin{tabular}{|l|l|}
\hline \multirow{5}{*}{ Maritime-Engineering Faculty } & Educational Program \\
\cline { 2 - 3 } & Maritime Navigation (GEO) - Bachelor \\
\cline { 2 - 3 } & Ships Power Plant (GEO) - Bachelor \\
\cline { 2 - 3 } & Maritime Navigation (ENG) - Bachelor \\
\cline { 2 - 3 } & Ships Power Plant (ENG) - Bachelor
\end{tabular}

Batumi State Maritime Academy

\begin{tabular}{|c|c|}
\hline \multirow{4}{*}{ Navigation Faculty } & Educational Program \\
\hline & Maritime Navigation (GEO) - Bachelor \\
\hline & Maritime Navigation (ENG) - Bachelor \\
\hline & Port Operations Management (GEO) - Master \\
\hline \multirow{4}{*}{ Engineering Faculty } & Ship Electro Mechanics (GEO) - Bachelor \\
\hline & Ships Power Plant (GEO) - Bachelor \\
\hline & $\begin{array}{l}\text { Operation of Ports And Transport Terminals (GEO) - } \\
\text { Bachelor }\end{array}$ \\
\hline & $\begin{array}{l}\text { Ship Power and Electrical Systems and Installations } \\
\text { (GEO) - Master }\end{array}$ \\
\hline
\end{tabular}

Note. Adapted from the institution's websites: www.bntu.edu.ge / www.bsma.edu.ge

Once a student has successfully completed their program and has completed maritime practice on board, he or she will gradually gain the necessary onboard experience required for a work license on board, which is necessary for a seafarer to undertake their responsibilities on board. 
The graduate also has the opportunity to be employed in private crewing, stewardship, consulting and other companies related to maritime transport.

As for the certification of seafarers, the 2020 report of the Maritime Transport Agency presents the statistics of certificates issued by the Seafarers' Certification Division during the reporting period 2020 y. (see Figure 1):

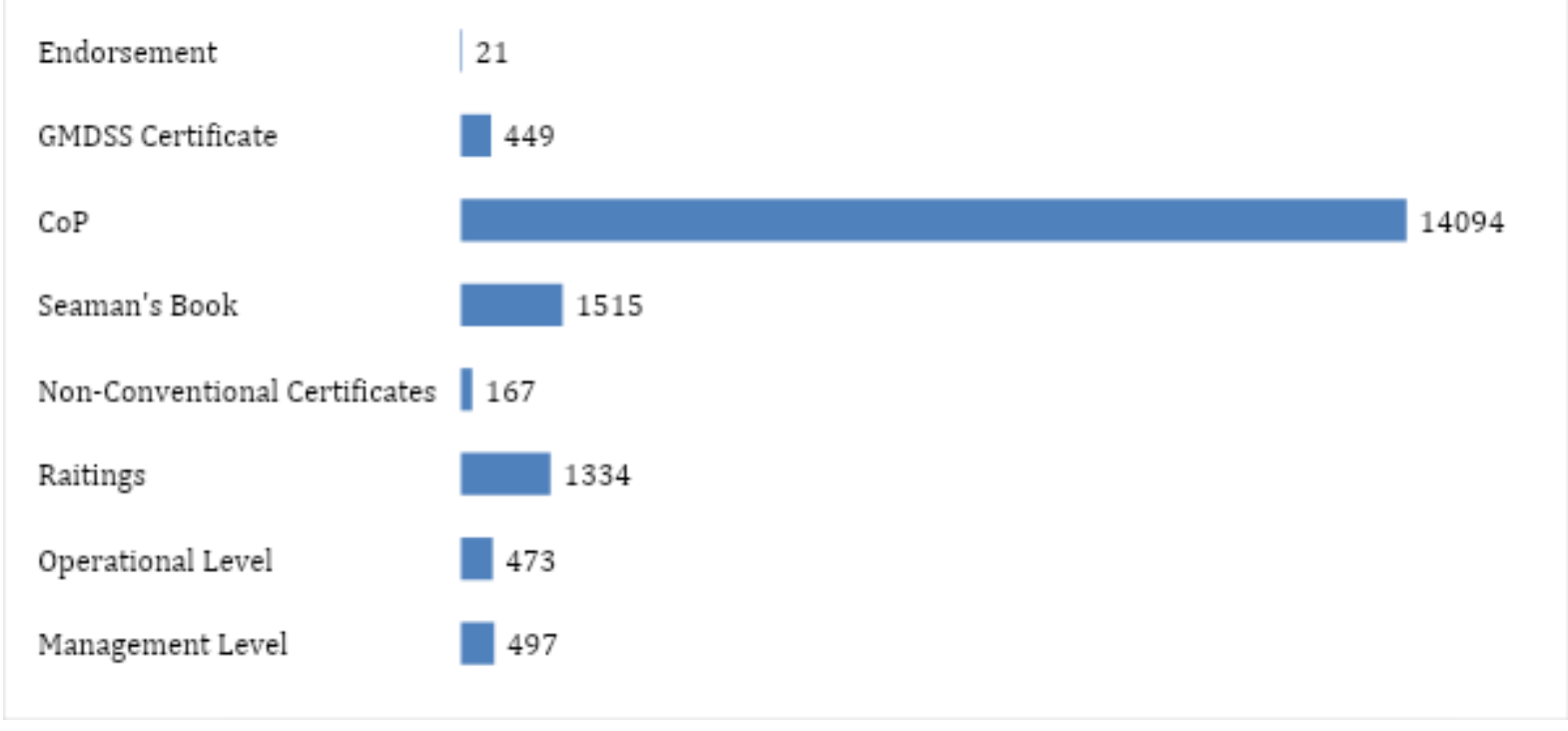

Figure 1. Certificates Issued by The Seafarers' Certification Division

Reproduced from Maritime Transport Agency of Georgia (2020). Annual Report: http://mta.gov.ge/uploads/2020__ 1.pdf

Today, 12,000 sailors are registered in Georgia, and maritime education is in demand in the country. As can be seen from the presented statistics, the certified seafarers rate and the number of active seafarers are also high.

\section{Challenges to MET in Georgia}

Although the country's highest maritime education institutions are authorized and programs accredited by the relevant authority, and comply with STCW requirements, there are still a number of challenges in maritime education. Maritime higher education institutions in Georgia face problems in different directions:

* One of the main is weakness of practice - cadets face serious obstacles in completing sea-going practices; Crewing companies operating in Georgia have low motivation to take cadets to the sea. All maritime institutions have a memorandum of understanding with existing crewing companies, which consider for the cadets to be provided with maritime practice, with the prospect of further employment. (ISSA, 2019) However, the main problem is that the cooperation is based on good will and it is quite unstable. Crewing companies periodically interview students and offer them cadet vacancies but that number is very small.

* A significant obstacle is the low level of English language teaching, which poses a serious obstacle to the employment of both students (cadets) and graduates in finding jobs on ships engaged in international navigation. Knowledge of English Language remains one of the major challenges despite the fact that many efforts are being made in this direction by maritime institutions. Learning the English language is important, not only for finding a job, but also for 
a good opportunity for the student to use exchange programs, such as Erasmus + ICM; Through exchange programs they are given a chance to communicate with students from another institution, another country, and this experience, in turn, will help them improve their language competence.

* Another challenge is shortage of academic staff in maritime institutions. However, active seafarers have low motivation to engage in training (mainly due to low pay); The maritime sector is rapidly evolving, where active seafarers are most informed about the nuances, specifics and technical characteristics required by today's maritime employment market. (ISSA, 2019) Institutions therefore try to attract as many active seafarers as possible; however, it is difficult to invite existing captains, or Chief Officers, and Chief Mechanics as teachers to an educational institution for two reasons: low salary and low motivation.

* Library resources of maritime institutions in Georgian Language are scarce - Maritime literature in Georgian is quite scarce; therefore, lecturers employed in educational institutions have to translate them and provide them to students within each lecture. Which is quite a lot of work, and the translation of a foreign textbook is quite expensive.

\section{Conclusion}

Despite the identified problems and challenges, Georgia's maritime education system is wellstructured, meets the requirements of the STCW and meets the requirements of the country's quality assurance standards set by the National Center for Educational Quality Enhancement. Consequently, Georgian seafarers are quite in demand and competitive in the world market. However, a number of measures to address these challenges would be helpful in eliminating these gaps.

It is desirable that institutional cooperation between maritime higher education institutions and crewing companies (major employers) be intensified in terms of student maritime practice. Also, it is desirable if the ships flying under the Georgia Flag will offer cadets positions to Georgian cadets with them.

It is important to strengthen the English language teaching component, and it will also be good if the institutions offer several specialty courses to students in English. By doing this, they will improve their level of English proficiency in the specialty and be ready for an interview.

It would be good if the institutions would establish relationships with their outstanding alumni for future collaboration, or this, it is desirable for the institution to assist the graduate in professional development and to train him / her in accordance with the requirements of the education standards, because in the future these graduates will be employed as invited specialists.

It is necessary to find financial resources (international and local grants) in order to translate specialty textbooks into Georgian.

\section{References}

Batumi Navigation Teaching University. (2021). Catalogue of undergraduate and graduate programmes. https://old.bntu.edu.ge/swavla/saganmanatleblo-programebis-katalogi 
Batumi State Maritime Academy. (2021). Educational programmes. https://bsma.edu.ge/page/sabakalavro-saganmanatleblo-programebi\#1

Maritime Transport Agency of Georgia. (2020). Annual Report 2020. http://mta.gov.ge/uploads/2020__ 1.pdf

Institute of Social Studies and Analysis [ISSA]. (2019). Maritime labour market survey. https://www.issa-georgia.com/en/legal-entity-of-public-law/acharis-ar-dasaqmebissaagento/140 